\title{
Corneal foreign body self-removal using polymer banknotes
}

Ch'ng Tun Wang, Koh Koon Ling, Niven Teh Chong Seong, Chong Mei Fong Hospital Raja Permaisuri Bainun, Ipoh, Perak, Malaysia

\section{Abstract}

Since the introduction of polymer banknotes, they have become a new tool for corneal foreign body (CFB) self-removal. Being easily available, lightweight, and sturdy, polymer papers have become a popular and innovative method to dislodge CFB. Although ophthalmology services are easily accessible in Malaysia, ignorance, lack of health awareness, and the desire to avoid medical costs are among the reasons why patients remove CFB themselves. The sequalae span from only a faint scar with relatively good vision to total blindness. Our case series highlights three cases of CFB self-removal using polymer banknotes and their sequalae. To echo what has been known previously, self-awareness and occupational hazard education remain the most important and effective way to prevent vision loss.

Keywords: corneal foreign body self-removal, polymer bank notes

Correspondence: Ch'ng Tun Wang MMed(Ophthal), Department of Ophthalmology, Hospital Raja Permaisuri Bainun, 30450 Ipoh, Perak, Malaysia.

E-mail:chngtw@yahoo.com 


\section{Pembuangan bendasing pada kornea menggunakan wang kertas polimer}

\section{Abstrak}

Sejak pengenalan kepada wang kertas polimer, ianya telah menjadi alat baru untuk mengeluarkan bendasing pada kornea (CFB). Kertas polimer yang mudah didapati, ringan, dan kukuh, telah menjadi kaedah yang popular dan inovatif untuk membuang CFB. Walaupun perkhidmatan oftalmologi mudah diakses di Malaysia, kejahilan, kekurangan kesedaran kesihatan, dan keinginan untuk mengelakkan kos perubatan adalah antara sebab mengapa pesakit membuang sendiri CFB. Sorotan komplikasi selepas itu berlaku dari hanya sekadar parut samar dengan penglihatan yang agak baik hingga kebutaan secara total dan kekal. Siri kes kami menyoroti tiga kes pengeluaran CFB menggunakan wang kertas polimer dan sekuelnya. Untuk mengetahui apa yang telah diketahui sebelumnya, kesedaran diri dan pendidikan bahaya pekerjaan tetap merupakan cara yang paling penting dan berkesan untuk mencegah kehilangan penglihatan.

Kata kunci: penyingkiran bendasing kornea, wang kertas polimer

\section{Introduction}

Corneal foreign body (CFB) is a common preventable ocular-related occupational injury. ${ }^{1,2}$ It comprises up to $58 \%$ of all ocular traumas. ${ }^{3}$ Although the majority of patients were wearing protective glasses when the accidents occurred, CFB was still reported at $43 \% .{ }^{4}$ Most CFB can be removed using a hypodermic needle under guidance with a slit lamp. It is a simple, quick, and safe procedure. Our case series highlights three cases of CFB self-removal (CFB-SR) using polymer banknotes and their sequalae.

\section{Case series}

The following three cases of CFB presented to the emergency eye clinic of Hospital Raja Permaisuri Bainun (HRPB) Ipoh, in Perak, Malaysia from 2016 to 2019. They were males aged 19 to 38 years. Only one of the patients was wearing goggles while grinding metal, while the other two did not wear any protective glasses when the accidents occurred. All three performed CFB-SR with a polymer banknote themselves prior to presenting to the eye clinic. The polymer banknote was folded several times (Fig. 1a) and the sharp edge was used to dislodge the CFB with an aid 




Fig. 1a. A polymer banknote was folded several times.

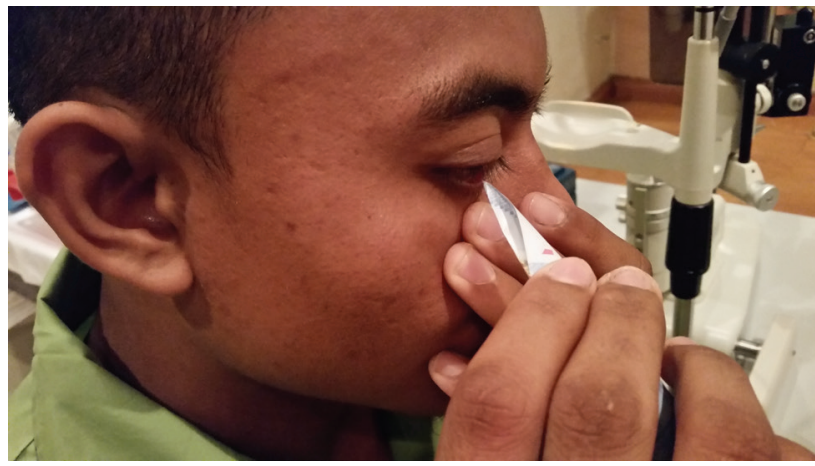

Fig. 1b. The sharp edge was used to dislodge the corneal foreign body.

of mirror or the help of an assistant (Fig. 1b). They only sought medical attention when they developed pain and redness associated with poor vision.

At presentation, all of them had central corneal ulcers with vision worse than 6/60. Corneal scraping for culture and sensitivity grew Pseudomonas aeruginosa from one of the ulcers, while no organism was identified in the other two eyes.

The ulcers responded well to intensive topical antibiotics. However, the long term sequalae differed between patients, with outcomes ranging from only a faint corneal scar to evisceration of the eye.

\section{Case 1}

A 35-year-old man presented with pain and redness in the left eye for 2 days after a foreign body entered the eye while welding. CFB-SR was done at home. On presentation, vision was hand movement with a large central corneal ulcer measuring $8 \times 8.5 \mathrm{~mm}$ and corneal thinning (Fig. 2). Corneal scraping revealed Pseudomonas aeruginosa. The ulcer responded well to antibiotics. It healed with a dense central corneal scar and a final visual acuity of hand movement. 


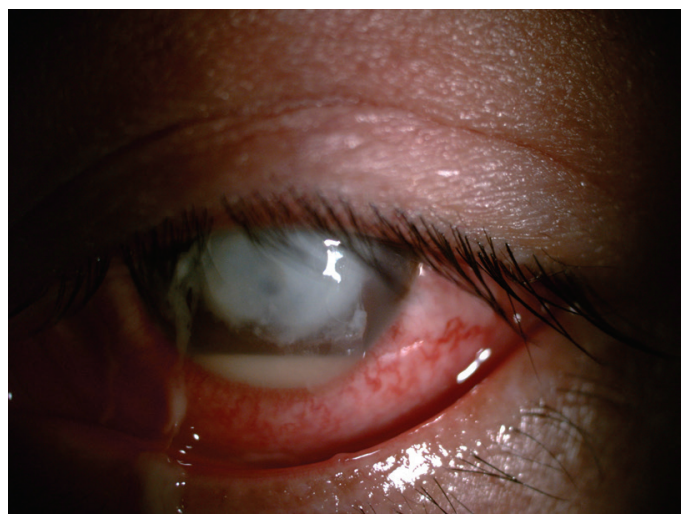

Fig. 2. Large and thin central corneal ulcer in the first case.

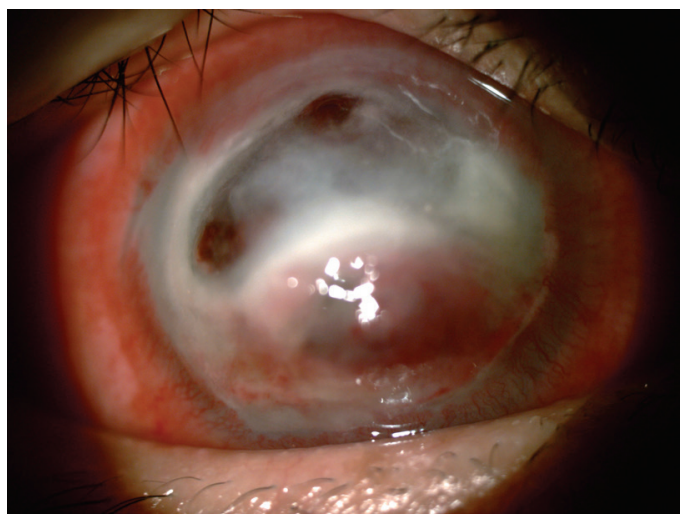

Fig. 3. Perforated corneal ulcer in the second case.

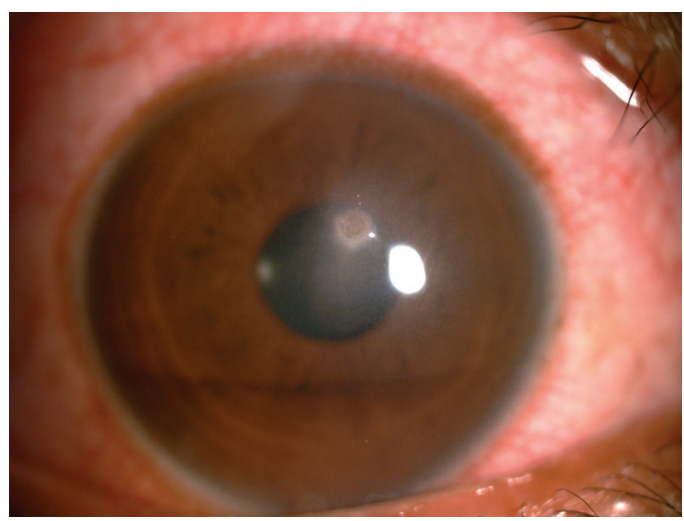

Fig. 4. Faint corneal scar in the third case. 


\section{Case 2}

A 38-year-old welder presented with pain and redness in the right eye with blurring of vision 1 week after a foreign body lodged in the eye while welding. CFB-SR was done by the patient. Vision was light perception at presentation. There was a large right corneal ulcer with peripheral corneal thinning (Fig. 3). Unfortunately, the ulcer perforated despite intensive antibiotics. The eye was eventually eviscerated.

\section{Case 3}

A 19-year-old man presented on day 2 of CFB-SR after foreign body entry into the right eye while grinding metal. He did not use protective eyewear. At presentation, visual acuity was $6 / 60$ with pinhole $6 / 36$. Upon examination, a central corneal ulcer of $2.4 \times 4 \mathrm{~mm}$ in size was noted. After 1 week of inpatient treatment, the corneal ulcer healed with faint scarring (Fig 4). His vision improved to 6/9.

\section{Discussion}

Direct visualisation with a slit lamp in a medical setting remains the safest method for CFB removal with a good visual outcome. Undeniably, some CFB are still removed in primary care settings without a microscope. Even though ophthalmology services are easily accessible in Malaysia, we are surprised that some patients still choose to remove CFB themselves. From the clinical history taking, we found that these patients removed the CFB themselves due to a lack of occupational hazard awareness and a desire to avoid medical costs.

There are several methods used for CFB-SR, including needles, toothpicks, paper cards, threads, and magnets. ${ }^{5}$ Needles and toothpicks are sharp and hard. In contrast, napkins and cloth are too soft, while paper cards become soft when in contact with tears. Recently, polymer banknotes have become a popular material utilized by individuals to remove CFB themselves. Being a polymer material, banknotes are lightweight and sturdy. They are also readily available.

Given they are designed for durability, actively circulating polymer banknotes harbour microorganisms, and specifically human pathogens, with the enteropathogen Escherichia coli being the most common. ${ }^{6}$ Hazem et al. found that the lower denominations were more contaminated than higher ones, ${ }^{6}$ as lower currency notes are exposed to more microorganisms due to high frequency of circulation.

CFB removal using a sharp object with no direct microscope visualisation may cause inadvertent injury to the adjacent healthy tissue. On top of that, incomplete CFB removal, such as retained residual rust rings, incites inflammation. Without proper topical antibiotic cover, CFB removal may predispose to ocular infection. 


\section{Conclusion}

In addition to what has been previously known, patients these days are becoming more creative in finding alternative ways to remove CFB themselves. This predisposes the delicate eye to risk of blindness. Therefore, self-awareness and occupational hazard education remain the most importance and effective ways to avoid blindness in these instances.

\section{References}

1. Islam SS, Doyle EJ, Velilla A, Martin CJ, Ducatman AM. Epidemiology of compensable work related ocular injuries and illnesses: Incidence and risk factors. J Occup Environ Med 2000;42:575-581.

2. Qayum S, Anjum R, Garg P. Epidemiological pattern of ocular trauma in a tertiary hospital of Northern India. Int J Med Clin Res 2016;7:420-422.

3. Voon LW, See J, Wong TY. The epidemiology of ocular trauma in Singapore: perspective from the emergency service. Eye (Lond). 2001;15:75-81

4. Zeynep et al. Metallic corneal foreign bodies: an occupational health hazard. Arq Bras Oftalmol. 2014;77(2):81-83

5. Arif Hussain et al. Metallic Corneal Foreign Body; A Preventable Work Related Cause of Ocular Morbidity. The Professional Medical Journal. 2019;26(4):688-691.

6. Hazem S, Mahmoud AM. Bacterial Contamination of Paper Banknotes in Circulation; a Case Study in the Jenin District, Palestine. Journal of Science. 2012;1(2):36-39 